\title{
Ozone profiles obtained by DIAL technique at Maïdo Observatory in La Reunion Island: comparisons with ECC ozone-sondes, ground-based FTIR spectrometer and microwave radiometer measurements.
}

T. Portafaix (1)*, S. Godin-Beekmann (3), G. Payen (2), M. de Mazière (4), B. Langerock (4), S.

Fernandez (5), F. Posny (1), J.P. Cammas (2), J. M. Metzger (2), H. Bencherif (1), C. Vigouroux (4), N. Marquestaut (2),

\section{(1) LACy (UMR 8105) - Université de la Réunion, Saint Denis, France, *thierry.portafaix@univ- reunion.fr \\ (2) OSU-Réunion - Université de La Réunion \& CNRS (UMS 3365), Saint Denis, France \\ (3) LATMOS-IPSL, Guyancourt, France \\ (4) BIRA-IASB, Brussels, Belgium \\ (5) IAP, University of Bern, Switzerland}

\begin{abstract}
A DIAL lidar system performing stratospheric ozone profile measurements from 15 to $45 \mathrm{~km}$ is installed at Reunion Island (southwest of Indian Ocean). The purpose of this communication is to present this DIAL system mounted now at the new Maïdo Observatory since February 2013, and the ozone profile retrieval. The first stratospheric ozone profiles obtained during 2013 and 2014 will be presented and discussed. Inter-comparison and differences observed with other high vertical resolution ozone profiles performed by ECC ozonesonde will be shown. Finally, comparisons with low vertical resolution ozone profiles retrieved from microwave and FTIR remote sensing measurements performed at Maïdo will be carried out, making appropriate use of the associated averaging kernels
\end{abstract}

\section{INTRODUCTION}

Reunion Island is situated in the Southwest of

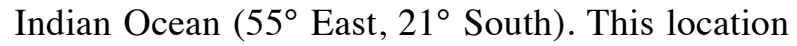
is particularly well suited for monitoring stratospheric ozone in the tropical belt of the southern hemisphere but also for studying quasihorizontal (isentropic) and vertical (stratospheretroposphere) exchange processes, variability and composition change of the tropical stratosphere in relationship with large-scale dynamics.

In support of these scientific topics, a new highaltitude observatory was built on the west coast of the island at $2200 \mathrm{~m}$ asl (Baray et al. 2013). It has been operating since October 2012 (Baray et al. 2013). The main objective of this station consists in observing the long-term chemical composition of the atmosphere in this region of the world where very few measurements are operational.

This facility called Maïdo Observatory hosts many instruments for monitoring the atmosphere by various techniques: in-situ measurements, radiosoundings, active and passive remote sensing experiments...

Stratospheric ozone measurements are regularly performed, on a routine basis following 3 experiments:

- a DIAL system to perform high-resolution vertical profiles of ozone in the $15-45 \mathrm{~km}$ altitude range

- a high spectral resolution Fourier- Transform infrared spectrometer (FTIR) operated by the Belgian Institute for Space Aeronomy ozone is measured between 10_40km

- balloonborn soundings with ECC component to measure ozone profiles from ground to $30 \mathrm{~km}$

In addition, a microwave radiometer of University of Bern, has operated between late 2013 and early 2015.

\section{STRATOSPHERIC DIAL SYSTEM AT REUNION ISLAND}


This LIDAR was installed at Reunion Island in 2000 and moved to Maïdo facility in 2013 after instrumental updates.

Like any DIAL system, it requires the use of a pair of emitted wavelengths.

Laser sources are a tripled Nd:Yag laser (SpectraPhysics Lab 150) and a $\mathrm{XeCl}$ excimer laser (Lumonics PM 844). The Nd:Yag provides the non-absorbed beam at $355 \mathrm{~nm}$ with a pulse rate of $30 \mathrm{~Hz}$ and a power of $5 \mathrm{~W}$, and the excimer provides the absorbed beam at $308 \mathrm{~nm}$ with a pulse rate of $40 \mathrm{~Hz}$ and a power larger than $9 \mathrm{~W}$. An afocal optical system is used to reduce the divergence of the beam to $0.5 \mathrm{mrad}$.

The receiving telescope is composed of 4 parabolic mirrors (diameter: $500 \mathrm{~mm}$ ). The backscattered signal is collected by 4 optical fibers located at the focal point of each mirror. The spectrometer used for the separation of the wavelengths is a Jobin Yvon holographic grating (3600 linesmm-1, resolution 3 A..mm-1, efficiency $>25 \%$ ).

The two Rayleigh beams at 308 and $355 \mathrm{~nm}$ are separated initially by the holographic grating and separated again at the output of the spectrometer by a lens system in the proportion $8 \%$ and $92 \%$, respectively, in order to adapt the signal to the non-saturation range of the photon-counting system. The optical signals are detected by 6 Hamamatsu non-cooled photomultipliers (PM). A mechanical chopper is used to cadence the laser shots and cut the signal in the lower altitude range where PM are saturated. This chopper consists of a steel blade rotating at $24000 \mathrm{rpm}$ in primary vacuum.

6 acquisition channels are recorded simultaneously: 2 channels at $355 \mathrm{~nm}$ corresponding to the lower and upper parts of the profile, 2 channels at $308 \mathrm{~nm}$ (lower and upper parts) and 2 Nitrogen Raman channels at 332 and $387 \mathrm{~nm}$. In addition to the mechanical gating, both upper Rayleigh channels at $355 \mathrm{~nm}$ and $308 \mathrm{~nm}$, are equipped with an electronic gating in order to cut the signals for the altitudes below $16 \mathrm{~km}$ and prevent signal-induced noise.

The system was moved to Maïdo Observatory by the end of 2012, after the update of the electronic system (now LICEL TR and PR transient recorders) and of the $\mathrm{XeCl}$ excimer laser. This new configuration allows us to obtain ozone profiles in the $15-45 \mathrm{~km}$ altitude range.

The lidar signals are recorded in a 3 min time file but averaged over the whole night acquisition (2 to $3 \mathrm{~h}$ time integration per night) to increase the signal-to-noise ratio.

It is necessary to apply different corrections to the signal. The background signal is estimated and removed using an average or a linear regression in the high altitude range where the useful lidar signal is negligible (over $80 \mathrm{~km}$ ). Another correction of the photomultiplier saturation for low layers is also required and applied.

The ozone number density is retrieved from the slope of signals after derivation (GodinBeekmann et al., 2003).

The lidar signals are corrected the Rayleigh extinction using a composite pressure temperature profile computed from nearby meteorological soundings performed daily at Reunion Airport and the Arletty model (based on meteorological data from the European Centre)

It is also necessary in the DIAL technique to use a low-pass filter. The logarithm of each signal is fitted to a 2 nd order polynomial and the ozone number density is computed from the difference of the derivative of the fitted polynomial. Varying the number of points on which the signals are fitted completes the filtering.

\section{OTHER STRATOSPHERIC OZONE INSTRUMENTS AT MAIDO FACILITY.}

A ground-based microwave radiometer (GROMOS-C) designed to measure middle atmospheric ozone profiles has been installed at Maïdo Observatory in 2014 and removed in early 2015. It has been specifically designed for campaigns and is remotely controlled and operated continuously under all weather conditions. It measures the pressure broadened line at $110.836 \mathrm{GHz}$ and can also measure the $\mathrm{CO}$ line at $115.271 \mathrm{GHz}$. The vertical profiles are retrieved by optimal estimation method (Fernandez at al., 2015). 
FTIR solar absorption measurements at high spectral resolution (from 0.0110 to $0.0035 \mathrm{~cm}^{-1}$ for ozone spectra) are performed by a Bruker 125HR spectrometer installed in 2013. This instrument is dedicated to NDACC measurements in the mid-infrared, covering the spectral range 600 to $6500 \mathrm{~cm}^{-1}$ (1.5 to $16 \mu \mathrm{m}$ ), and particularly the ozone retrievals are performed using the 1000$1005 \mathrm{~cm}^{-1}$ window in the $600-1400 \mathrm{~cm}^{-1}$ spectra (MCT detector, $\mathrm{KBr}$ beam-splitter). From the measured absorption spectrum, an inverse method (optimal estimation method) is used to trace back the vertical abundance profiles of gases present in the atmosphere. For ozone, information on about four independent layers in the atmosphere can be retrieved, roughly one in the troposphere and three in the stratosphere, up to about $45 \mathrm{~km}$ (Vigouroux et al., 2008). This instrument is operated remotely and automatically with an updated version of the BARCOS system (Neefs et al., 2007). In addition to the continuous monitoring of the atmospheric chemical composition and transport processes, the intention is also to participate to dedicated observations campaigns.

In addition, ECC ozone soundings are performed weekly at Reunion Island since 1998. The ozonesonde currently used is of ECC Z Ensci type with a $0.5 \%$ KI buffered solution from Droplet Measurement Technology [DMT]. It is coupled to a meteorological radiosonde M10 from MeteoModem. The effective vertical resolution of the ozone data is between 50 and $100 \mathrm{~m}$ [Thompson et al., 2003a,b, 2007]. The ozone measurement accuracy is around $\pm 4 \%$ in the stratosphere below 10 mbar pressure level and the precision in total ozone column measured by the ECC sonde is around 5\%. These ozone measurements are part of the SHADOZ (Thompson et al., 2003a, 2003b) and NDACC networks.

\section{INTER- COMPARISONS}

The first comparisons with ECC simultaneous sounding are very encouraging (Baray et al. 2013) with differences less than $10 \%$ throughout the profile. Figure 1 presents an example for June 23, 2014.

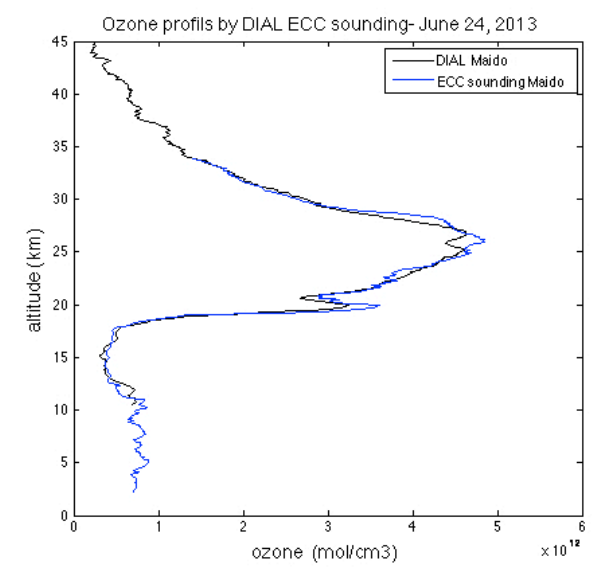

Fig 1: Ozone profiles on 24 June 2013 by stratospheric DIAL (black line) and ECC-ozonesonde at Mä̈do Observatory (blue).

Other comparison between DIAL and GROMOS $-\mathrm{C}$ ozone profiles after applying the averaging kernel show a very good agreement in the layer between 5 and $20 \mathrm{hPa}$, with differences less than 5 $\%$. But differences are more important on the lower or upper layers. It can reach more than 15 $\%$ in the $20-100 \mathrm{hPa}$ layer.

These comparisons with the microwave radiometer were made using the DIAL "Rapid Delivery" profiles for the NDACC network, using average parameters for photomultiplier desaturation and background signal removing.

These medium parameters can introduce some additional error in the lower or upper part of the resulting profiles. It will be important for the final version of this paper to make these comparisons from consolidated lidar profiles using refined parameters.

The stratospheric ozone LIDAR is already NDACC qualified. It should be noted however that an inter-comparison campaign of all the NDACC lidar systems (water vapor, temperature, ozone) installed the Maïdo Observatory with the mobile system of NASA-GSFC (McGee et al., 1995) is planned for May 2015.

Comparisons with FTIR will be performed for the three layers between 15 and $45 \mathrm{~km}$. The FTIR measurements in the ozone spectral range will be intensified during this 2015 intercomparison campaign. 


\section{ACKNOWLEDGEMENT}

The present work is supported by LACy, OSURéunion and the FP7 European NORS project. The authors acknowledge the European Community, the Région Réunion, the CNRS, and the University of La Réunion for their support and contribution in the construction phase of the research infrastructure OPAR (Observatoire de Physique de l'Atmosphère à La Réunion). OPAR and LACy are presently funded by CNRS (INSU) and Université de La Réunion, and managed by OSU-R (Observatoire des Sciences de l'Univers à la Réunion, UMS 3365). We acknowledge Anne M. Thompson (NASA/GSFC, USA) the SHADOZ network principal Investigator, and E. Golubic, P. Hernandez and L. Mottet who are deeply involved in the routine lidar measurements at Maïdo facility.

\section{REFERENCES}

[1] Baray, J.-L., Courcoux, Y., Keckhut, P., Portafaix, T., Tulet, P., Cammas, J.-P., Hauchecorne, A., Godin Beekmann, S., De Mazière, M., Hermans, C., Desmet, F., Sellegri, K., Colomb, A., Ramonet, M., Sciare, J., Vuillemin, C., Hoareau, C., Dionisi, D., Duflot, V., Vérèmes, H., Porteneuve, J., Gabarrot, F., Gaudo, T., Metzger, J.-M., Payen, G., Leclair de Bellevue, J., Barthe, C., Posny, F., Ricaud, P., Abchiche, A., and Delmas, R.: Maïdo observatory: a new high-altitude station facility at Reunion Island $\left(21^{\circ} \mathrm{S}, 55^{\circ} \mathrm{E}\right)$ for long-term atmospheric remote sensing and in situ measurements, Atmos. Meas. Tech., 6, 28652877, doi:10.5194/amt-6-2865-2013, 2013.

[2] Fernandez, S., A. Murk, and N. Kämpfer, GROMOS-C, a novel ground based microwave radiometer for ozone measurement campaigns, Atmos. Meas. Tech. Discuss., 8, 3001-3048, 2015 www.atmos-meas-tech-discuss.net/8/3001/2015/ doi:10.5194/amtd-8-3001-2015

[3] Godin-Beekmann, S., J. Porteneuve, A. Garnier, Systematic DIAL ozone measurements at Observatoire de Haute-Provence, J. Env. Monitoring, 5, 57-67, 2003

[4] McGee, T. J., Gross, M. R., Singh, U. N., Butler, J. J., and Kimvilakani, P. E.: Improved stratospheric ozone lidar, Opt. Eng., 34,14211430, 1995.

[5] Neefs, E.; de Mazière, M.; Scolas, F.; Hermans, C.; Hawat, T.: BARCOS, an automation and remote control system for atmospheric observations with a Bruker interferometer, Rev. Sci. Instrum., 78, 035109:1-035109:8, 2007.

[6] Thompson, A. M., et al. (2003a), Southern Hemisphere Additional Ozonesondes (SHADOZ) 1998-2000 tropical ozone climatology: 1. Comparison with Total Ozone Mapping Spectrometer (TOMS) and ground $\square$ based measurements, J. Geophys. Res., 108(D2), 8238, doi:10.1029/ 2001JD000967.

[7] Thompson, A. M., et al. (2003b), Southern Hemisphere Additional Ozonesondes (SHADOZ) 1998-2000 tropical ozone climatology: 2. Tropospheric variability and the zonal wave $\square$ one, J. Geophys. Res., 108(D2), 8241, doi: 10.1029/ 2002JD002241.

[8] Vigouroux, C., De Mazie're, M., Demoulin, P., Servais, C., Hase, F., Blumenstock, T., Kramer, I., Schneider, M., Mellqvist, J., Strandberg, A., Velazco, V., Notholt, J., Sussmann, R., Stremme, W., Rockmann, A., Gardiner, T., Coleman, M., and Woods, P.: Evaluation of tropospheric and stratospheric ozone trends over Western Europe from ground-based FTIR network observations, At- mos. Chem. Phys., 8, 6865-6886, doi:10.5194/acp-8-6865-2008, 2008. 